\title{
CONCEPTIONS OF SPEECH ACTS IN THE THEORY AND PRACTICE OF ARGUMENTATION: A CASE STUDY OF A DEBATE ABOUT ADVOCATING
}

\begin{abstract}
Far from being of interest only to argumentation theorists, conceptions of speech acts play an important role in practitioners' self-reflection on their own activities. After a brief review of work by Houtlosser, Jackson and Kauffeld on the ways that speech acts provide normative frameworks for argumentative interactions, this essay examines an ongoing debate among scientists in natural resource fields as to the appropriateness of the speech act of advocating in policy settings. Scientists' reflections on advocacy align well with current scholarship, and the scholarship in turn can provide a deeper understanding of how to manage the communication challenges scientists face.
\end{abstract}

Keywords: argumentation; metadiscourse; speech acts; science-policy interface; advocacy; advice

Speech act theory may appear to be one of the most abstruse approaches to conceptualizing argumentative activities. The theory has a deep base in the philosophies of J.L. Austin (1962), Paul Grice (1957) and John Searle (Searle, 1969) - a literature characterized by dense lists of recursive intentions and felicity conditions. In this paper, I hope to show that far from being an esoteric domain accessible only to argumentation theorists, conceptions of speech acts are conspicuous in ordinary argumentative practice. Arguers in practice understand, explain and defend what they are doing by reference to speech acts. And this convergence between theory and practice opens space for a conversation that both sides may find fruitful.

To explore the convergence, I develop in this essay a case study of the conceptions that emerged in the course of a debate among scientists about how they should participate in policy-making. I show that the scientists focused on the speech activity of advocating in order to identify the responsibilities they undertake when giving reasons in controversy-laden situations. Speech act theories developed by argumentation scholars, and in particular Fred Kauffeld, do not serve to replace these practitioners' sense 


\section{Jean Goodwin}

of what they are doing. Rather, academic speech act theory can help clarify scientists' debates over appropriate participation, and can also offer them additional practical options. In turn, theorists have much to learn from conceptions of speech acts that have proved sufficiently robust to survive the challenges of practice.

As an investigation of practitioners' own theories of argumentation, this paper adds to a growing literature that attempts to bridge the "abyss" between theorists' and practitioners' conceptions (Plantin, 2002) by recognizing instead a theory/practice continuum (Craig, 1996). Scholars on both sides of the Atlantic have long noted that arguers in practice deploy a sophisticated metadiscursive vocabulary as they try to regulate their own and each other's conduct (Craig, 1999; Plantin, 1996). Indeed, "argument" is itself a technical term that practitioners use to organize and explain what they are doing (Craig, 2011; Craig \& Tracy, 2010; Doury, 2008; Goodwin, 2007b; Plantin, 1996). Such metadiscursive commentaries on ordinary practice may become particularly prominent when the practice is under dispute (Philipsen, 1992). This case study of a debate about appropriate practice establishes that speech acts provide an important interpretive resource for arguers. Argumentation theorists should therefore continue to take speech act theory seriously, if they want to claim "conventional validity" (Eemeren, Grootendorst, Jackson, \& Jacobs, 1993), i.e. fit between their theories and the conceptions of argumentation at play in ordinary argumentative practice.

In the following pages, I begin with a survey of approaches to speech acts developed within the interdisciplinary argumentation theory community. I then turn to an examination of how U.S. natural resource scientists invoke speech acts in the course of a debate about their appropriate participation in public life. Finally, I close by bringing theory and practice into conversation.

\section{Speech acts in argumentation theory: An overview}

Central to several contemporary approaches to argumentation is the idea that an arguer's initiating speech act creates an obligation to produce arguments with definite characteristics - e.g., arguments for a certain proposition, of a certain amount, with certain qualities. An arguer's initiating speech act, in other words, helps regulate the interaction between people who disagree (an argument-2, in O'Keefe's [1982] terms) by establishing a local normative framework that requires the making of argument-1s that are good in specified ways. Thus in contrast to approaches which derive norms 
of argumentation from types of interactions or dialogues (e.g., Walton, 1998) or from a general practice (Johnson, 2000), the speech act approach posits that it is the arguers' own activity which provides part of the framework for a productive exchange of arguments (Goodwin, 2007a).

This core idea has long been embedded in the theory associated with the U.S. tradition of forensic debate. Ehninger and Brockriede's seminal textbook Decision by Debate (1963) uses an analogy of one person trying to seize a piece of ground - a position - currently held by another. Physically pushing the person off the ground would both have force and run a risk, namely a risk of reprisal. Similarly, asserting a claim to the position "is an agitating force; it has the effect of stirring up and throwing into turmoil what had previously been a static and ordered situation." At the same time, "although less direct physical danger may be involved in the verbal declaration than in the shove," the assertor "still takes a risk when he asserts that [the position] by rights belongs to him, for, unless his claim is to be idle talk, he must be able to prove the necessity, expediency, or justice" of his claim, with good arguments (p. 82). An arguer who asserts a claim thus undertakes the obligation to defend that claim with good arguments.

In a series of essays, Peter Houtlosser works within the pragmadialectical framework put forward by van Eemeren and Grootendorst (1984), providing a considerably more sophisticated account of the initiating speech act as it occurs not only "in formalised, regimented" interactions such as a forensic debate, but also "in informal, non-regimented discussions" (Houtlosser, 1998, p. 397). In Houtlosser's Searle-inspired analysis, the speech act advancing a standpoint cannot be identified simply with the performance of an assertive (Houtlosser, 2002); Houtlosser would find the hoary maxim "he who asserts must prove" to be fundamentally misguided. Advancing a standpoint, first of all, functions at a "higher textual level" (Houtlosser, 1994); it establishes the point around which an entire interaction will revolve. The felicity conditions require that the act be done in a specific interactional context, namely one in which the speaker believes that the listener does not accept the proposition being put forward (Houtlosser, 1998). And the essential condition establishes that that advancing a standpoint "counts as taking responsibility for a positive position in respect of [a proposition], i.e. as assuming an obligation to defend a positive position in respect of [that proposition] if requested to do so" (Houtlosser, 1998, p. 390). The speech act advancing a standpoint thus initiates an argumentative interaction in which the speaker ought to, intends to, and believes he can, justify his position. 


\section{Jean Goodwin}

Sally Jackson has provided additional elaborations. In work that has also contributed to the pragma-dialectical program (Eemeren, Grootendorst, Jackson, \& Jacobs, 1993), Jackson has shown how many different speech acts can create frameworks for argumentative interactions. Whereas in the speech act advancing a standpoint (and in assertive speech acts generally) the focus is on the propositional content asserted, Jackson points out that in fact, a speaker is also committed to defend the legitimacy of all the felicity conditions of his act. As she puts it:

the single most useful contribution of speech acts theory is in explaining how certain things come to be at issue in an argument. In the theory of speech acts, the performance of any act is seen as committing the speaker, in principle, to the set of beliefs and intentions embodied in the felicity conditions. Thus, the performance of a request, promise, or other act carries with it a package of commitments, expressible as propositions, and representing the beliefs associated with felicitous acts of that type. The speaker does not advance this series of subordinate propositions on their own merits, but incurs responsibility for them by virtue of performing an act for which they are rational or conventional prerequisites. Conversational argument is full of bizarre little interludes whose bearing on what might be called the issue can only be understood as depending on the preconditions of some superordinate speech act (Jackson, 1985, pp. 128-129).

In complaining that a co-worker keeps showing up late, for example, a speaker not only takes responsibility for the truth of his statement about his colleague; he also takes responsibility for the bearing of the lateness on his own concerns, for the sincerity of his distress at the conduct, and for the legitimacy of his right to demand attention to his complaint from his addressee. Although a speaker does not expressly advance such "virtual standpoints," they can potentially be called out by the addressee; together, they constitute the "disagreement space" of propositions that (under the right circumstances) a speaker can be obligated to defend (Jackson, 1992).

Fred Kauffeld provides a final set of nuances to our understanding of how speech acts serve to initiate and frame argumentative interactions. Like Jackson, Kauffeld recognizes that many speech acts are relevant to argumentation theory. But working in a Gricean tradition (Kauffeld, 2001, 2009), Kauffeld focuses less on the diversity of the propositions to which speakers are committed and more on the diversity of the commitments themselves. In the basic act of saying something seriously, a speaker makes evident her intention to induce her addressee to believe her; in doing so, she openly undertakes a commitment to veracity, a commitment that in turn justifies her addressee's trust (Moran, 2006; Stampe, 1967). To meet the pragmatic chal- 
lenges of specific situations, a speaker can expressly enhance or restrict this basic commitment to the truth of what she is saying, and thus also enhance or restrict her commitment to justify it with good arguments. Patterns of such commitments that meet recurrent situational demands are given names and recognized as distinct speech acts. For example, in proposing a speaker wants to secure tentative consideration from an addressee who likely has better things to do than lend her an ear. To earn her addressee's attention, the speaker undertakes an obligation to answer all doubts and objections to the proposal; in other words, she undertakes a substantial burden of proof. Her addressee can then reason that the speaker would not do this unless she was confident that her proposal could withstand critical scrutiny, and thus further that his attention is unlikely to be wasted (Kauffeld, 1998, 1999, 2002). On the opposite extreme, in order to allow a free flow of potentially important social information, in gossiping a speaker expressly waives a commitment to veracity and even sincerity (Kauffeld \& Fields, 2003); gossipers thus undertake no obligation to make good arguments. Nor is it just the speaker who finds herself subject to obligations to make arguments of a certain quality; in some circumstances, the speaker's conspicuous fulfillment of her argumentative obligations exercises a legitimate force on her addressee, imposing on him in turn an obligation to respond appropriately (Kauffeld, 1995, 2009). Speech acts in Kauffeld's view are thus sophisticated tools through which arguers craft a local "normative terrain" (Goodwin, 2007a) binding them both throughout their entire argumentative interaction.

Houtlosser, Jackson and Kauffeld each demonstrate how an initiating speech act can provide part of the normative framework necessary to coordinate a productive argumentative interaction between people who disagree, perhaps deeply. The speech act serves to pick out the point being argued about and to establish the nature and extent of arguers' specific responsibilities to make good arguments. Especially in the approaches of Jackson and Kauffeld, many different speech acts can be used to accomplish these tasks. In any given case, arguers thus have a choice of the speech act to use to initiate their interaction. I turn now to a case study of how one community of argument practitioners is reasoning about that choice.

\section{Speech acts in argumentative practice: the debate over advocating by scientists}

There is a recurring problem in civic life about how experts can productively contribute their knowledge to debates over public policy. Dealing with 


\section{Jean Goodwin}

this general problem has been a special concern for U.S. scientists working in natural resource-related fields such as ecology, conservation biology, invasion biology, marine biology, wildlife management and forestry. These fields produce knowledge that is actively sought out by the resource managers and regulators (Mills \& Clark, 2001; Steel, List, Lach, \& Shindler, 2004). Their love of the natural world also propels these scientists into policy arenas, especially when they perceive the biodiversity and ecosystems they cherish under imminent threat (Barry \& Oelschlaeger, 1996; Myers, 1999). So it is not surprising that scientists in these fields have long been struggling with how best to participate in public life (Nelkin, 1977), and that the issue has been subjected to repeated discussions in dedicated fora at the fields' conferences and in the fields' journals (e.g., Conservation Biology 10.3, 1996; 21.1, 2007; Human Dimensions of Wildlife 6.1, 2001; BioScience 51.6, 2001).

A variety of topics have been raised in the course of this debate. There are discussions about whether science is a value-laden or value-free activity (Barry \& Oelschlaeger, 1996; Tracy \& Brussard, 1996) and about whether participating in policy-making hinders scientists' careers (Foote, Krogman, \& Spence, 2009; Nelson \& Vucetich, 2009). Of interest for us here is a question this community of scientists persistently asks about the kinds of speech acts appropriate for scientists in policy controversy, and in particular, whether scientists should advocate.

What do these scientists mean when they talk of "advocacy"? At times, scientists use the term very broadly to refer to any sort of intervention in the policy process (e.g., Brussard \& Tull, 2007). As one scientist commented, however, this usage is likely the result of excess wariness over possible politicization of their work (Blockstein, 2002). More commonly, the focus of the discussion of advocacy is on a particular speech activity: communication intended to increase adherence to some specific policy proposal. Explicit definitions of the speech activity of advocating by scientists include:

Policy advocacy: active, covert, or inadvertent support of a particular policy or class of policies (Lackey, 2007, p. 13).

Simply defined, advocacy means to write or speak in support of something (Gill, 2001, p. 22).

Advocacy is, first, comparing the most plausible of a collection of possible propositions, explanations, or descriptions of an issue, and then lending one's active support to the ideas, policies, or proposals that are interpreted by the researcher to offer the most compelling match between the existing conditions and policy to address or improve it (Foote et al., 2009, p. 581). 
Examples of advocacy mentioned in the debate include calling for passage of legislation protecting endangered species (Nelson \& Vucetich, 2009, p. 1091), speaking out for action to stop climate change (Lovejoy, 1989), and intervening in governmental decisions about clean water standards (Karr, 2006). Such advocacy is not carried out exclusively by making arguments; scientists understand that the term also embraces activities like "camping out in the canopies of redwoods or lying down in front of bulldozers" (Gill, 2001, p. 19). But as one scientist noted, "the word advocacy...has other important connotations: of responsibility; of support; and of bearing witness to the evidence that, as a scientist, one has gathered and weighed" (Karr, 2006, p. 288). Throughout the debate, scientists recognize that advocates paradigmatically proceed by making arguments. For example:

Advocacy occurs when, during the process of communicating research results, ecologists use scientific facts to shape an argument relevant to a particular policy goal (Morrison \& Ayres, 2010, p. 50)

Advocacy involves advancing the most convincingly reasoned suggestions for change, informed by defensible, rigorous evidence (Foote et al., 2009, p. 584)

Scientists thus perceive the speech activity advocating as providing an overall framework within which they offer arguments in policy controversies. Is that speech activity appropriate? I now review some of the arguments scientists give on both sides of this question, as a way of elucidating this community's implicit conception of the relationship of speech acts to argumentative responsibilities.

Defenders of the legitimacy of advocacy point out that scientists' expertise positions them to be outstanding advocates. "Science is central to the decisions" contemporary policy-makers must make, one comments,

and scientists are uniquely qualified to apply that science to the decisionmaking process. Scientists do more than collect data. Their training, and the day to-day practice of their profession, centers on gathering evidence for and against hypotheses, weighing that evidence, and drawing conclusions based on the evidence. Their analytical expertise, coupled with detailed knowledge in particular fields of study, equips them to understand and explain scientific conclusions and describe how that information is relevant to a specific policy context or situation.... The training that scientists receive - to question the assumptions and conventions of science - also equips them to challenge the assumptions of public policy, the law, and implementation of the law (Karr, 2006, p. 287).

In many cases, scientists are thus both "the best arbiters of whether a premise is objective and true," and also, "given their high level of skill and 


\section{Jean Goodwin}

training in rational thought,... better prepared than many citizens to construct and assess arguments representing policy" (Nelson \& Vucetich, 2009, p. 1085). For some, scientists' expertise not only equips them to be better at making arguments, it actually obligates them to do so. "Indeed it is our responsibility," one scientist insists, "as those who understand best what is happening and what alternatives exist, to sound the tocsin about environmental deterioration and conservation problems in all their variety" (Lovejoy, 1989, p. 330). Scientists share the general obligation of all citizens to advocate for what they believe within the deliberative process, and even more, since "scientists are distinctive among citizens because they possess a distinctively valuable understanding of objective analysis and descriptive facts about the world" they have "a strong obligation" to do so (Nelson \& Vucetich, 2009, p. 1099). And if they don't live up to this obligation, others with less knowledge and understanding - special-interest groups, lawyers, religious leaders, legislators, and judges" (Foote et al., 2009, p. 582)—will step in to fill the gap, to the detriment of the policy process. As an article by a particularly trenchant pair of scientists concluded,

ultimately it is a perversion of democracy to muffle the voice of the most knowledgeable among us, and consequently amplify the voice of those with the greatest ignorance. Silencing scientists who wish to be just and transparent advocates promotes mob rule or despotic rule by special interests (Nelson \& Vucetich, 2009, p. 1099).

On the other side, opponents argue that advocacy by scientists will undermine the special respect that the public grants them. Some point out that advocacy will have an unfortunate impact on scientists' objectivity, with confirmation bias distorting scientists' judgment of what to study, how to study it, and how to interpret the results (Nielsen, 2001; Wiens, 1997). Others point out that even if the scientist remains psychologically objective, he will not appear objective to public audiences because the norms that structure the activity of advocacy and the practice of science are incompatible. As one scientist explains, science and advocacy are orthogonal "dimensions" which lead in different directions:

Many conservationists are proudly zealous about being environmental advocates, and they see science as an excuse by some to be apathetic. Actually, science requires an open-minded approach that can accept new models of what is known, supported by new data and analyses. Thus, it is difficult for a scientist zealously to advocate singular solutions to environmental problems except under the simplest of circumstances. It also follows that it would be difficult unswervingly to advocate a particular solution to a complex environmental 
problem without depending upon a certain amount of dogma as a source of knowledge. Thus, in the extreme, the knowledge and advocacy dimensions interact such that objective scientists cannot ordinarily be zealous activists, and zealous activists cannot be constrained by objective science as a sole source of knowledge (Tracy \& Brussard, 1996, p. 918)

Another scientist makes a similar point, differentiating between the commitments undertaken by advocates and scientists:

[Advocates] have made a commitment to a particular idea, philosophy, perspective, value, person, place, and so forth. Having made such a commitment, they work to convince others to accept their viewpoint and make the same commitment. Scientists and professionals, in contrast, write or speak in support of nothing. The only commitment scientists and professionals have made is to their current understanding of the truth (Nielsen, 2001, pp. 40-41).

Scientist-advocates will thus likely display the same passion, selective use of evidence, and character attacks that political advocates ordinarily do (Aron, Burke, \& Freeman, 2002). But as they do so, they will be conspicuously abandoning the normative standards that gave them authority in the first place. Thus the "environmental advocate loses power to persuade because the advocate is seen as not being open-minded and objective about solutions to environmental problems" (Tracy \& Brussard, 1996, p. 918). One scientist termed this a "paradox," explaining that

when professionals decide to use the power of their expert knowledge to control policy outcomes, the public image of professionalism subtly metamorphoses. It transforms the professional's role from reliable expert into competing interest, and credibility erodes. The erosion of credibility reduces political power and a paradoxical futile cycle ensues. The paradox lies in the fact that the political power of professionals can be retained only if it is not exercised (Gill, 2001, pp. 22-23).

In this view, scientists can advocate; but if they do so, they will stop being perceived as scientists.

The concern that advocacy by scientists erodes scientific credibility is a significant one, mentioned by practically every scientist who contributed to the debate. Scientist-advocates appear to face what climate scientist Stephen Schneider famously termed the "double ethical bind" (Schneider, 1988) that plagues science communication generally. Advocacy and the practice of science are both normatively structured. But the norms of the two activities conflict. What it takes to be good at one of the activities is incompatible with what it takes to be good at the other, so scientists 


\section{Jean Goodwin}

are constantly confronting choices like whether to be up front about uncertainties (good science, poor, overly-complex public communication) or to simplify uncertainties (good public communication, poor science). This dilemma, like perhaps all the dilemmas that underpin communication practices, cannot be resolved; but it can be managed (Craig \& Tracy, 1995). The central issue in the debate thus becomes not whether scientists should advocate in either the general or specific sense, but how they should do so:

How should we as citizen-scientists participate in the arena of public policy, as individuals and as a professional scientific society? How do we best meet the simultaneous demands of science and citizenship? How can scientists promote the timely and responsible use of scientific information and concepts in the policy-making process (Meine \& Meffe, 1996, p. 916)?

Two main strategies for managing this dilemma are evident within the debate. Proponents of advocacy aim to integrate the two sets of norms into a new approach to communication; opponents of advocacy aim to identify other speech acts whose norms are less in tension with the norms of science.

Consider the first strategy: the proposal that advocacy and science should be integrated. In this approach, the central question that needs to be addressed is "what general qualities should characterize [scientists'] advocacy?" (Nelson \& Vucetich, 2009, p. 1091). Proponents argue that scientist-advocates should take on additional responsibilities in order to preserve their authority while also defending their position. They variously call such advocacy-plus "responsible advocacy" (Foote et al., 2009), "honest advocacy" (Noss, 2007), or "justified, transparent advocacy" (Nelson \& Vucetich, 2009); its special obligations are said to include:

1. Scientist-advocates should change their public positions when the evidence demands it (Meyer, Frumhoff, Hamburg, \& de la Rosa, 2010; Nelson \& Vucetich, 2009; Noss, 2007).

2. Scientist-advocates should not (like "sophists"—Nelson \& Vucetich, 2009) use the most effective arguments for their policy positions; they should use only the best available, peer-reviewed, data-supported science to make their cases (Blockstein, 2002; Foote et al., 2009; Meyer et al., 2010; Nelson \& Vucetich, 2009).

3. Scientist-advocates should be fully open about uncertainties, margins of error, caveats and limitations (Blockstein, 2002; Meyer et al., 2010).

4. Scientist-advocates should bring forward counter-considerations that weigh against the policies for which they advocate (Foote et al., 2009; Lach, List, Steel, \& Shindler, 2003; Nielsen, 2001) 
These and other supererogatory commitments bring the normative structure of advocacy closer to that of science, reducing or eliminating the conflict that threatened to undermine the credibility of the scientist-advocate.

By contrast, critics of advocacy by scientists frame the central question of how scientists should participate in policy controversies as one of choice between multiple options:

There are many ways to express and act upon values, and the most effective are not necessarily the most visible or audible. Values express themselves differently among different people, and our chosen modes of expression necessarily change from time to time and according to circumstances. ...Where one can best devote one's energies, what points one choses to advocate, and when one should shift strategies are matters of personal conscience, insight, and choice (Meine \& Meffe, 1996, p. 917).

In this approach, scientific credibility can be reconciled with full participation in the policy process by directing attention to the many ways scientists can contribute, over and above advocacy. In a recent editorial, two leading scientists urge going beyond the oversimplified debate about advocacy:

We suggest it is time to shift the question from whether conservation professionals should be advocates to how the expertise of scientists and professional societies can be given greater weight in ongoing discussions regarding policies and management actions that affect biological diversity.... The notion that a scientist is either an advocate or does nothing at all to shape policy is a false dichotomy that has muddied the debate about science and advocacy. We agree that doing nothing to help shape environmental policy is irresponsible. We do not believe, however, that our choices are either advocate or do nothing (Scott \& Rachlow, 2011, pp. 2-3)

One of the earliest lists of options included the speech activity of advocating along with four alternative acts/activities:

- reporting scientific results that others use in making decisions on natural resource management issues,

- reporting and then interpreting scientific results for others who are involved in natural resource management decisions,

- working closely with managers and others in integrating scientific results into management decisions

- actively advocating for specific and preferred natural resource management decisions, and

- making decisions about natural resource management and policy (Lach et al., 2003, p. 174). 


\section{Jean Goodwin}

Related lists of potential speech acts by scientists include "Data, Interpretation, Advice, Counsel, Advocacy" (Blockstein, 2002, p. 92); reporting, answering questions, evaluating options, advocating (Scott, Rachlow, \& Lackey, 2008p. 867, borrowing from Pielke, 2007); and educating, promoting, and advocating (Minnis \& Stout McPeake, 2001).

Although the debate among scientists over how to contribute to policymaking continues, my survey of it cannot. I have discussed the way that scientists frame the debate as one over the appropriateness of a particular speech activity - advocating. Proponents of advocacy by scientists argue that advocacy is permissible - even obligatory - and that in a modified form, is compatible with the norms of good science. Opponents of advocacy by scientists argue that the norms of advocacy and science are incompatible, and that it is best to seek alternative speech acts for public participation. It is now time to step back and bring theorists and practitioners into conversation, asking how the conceptions of speech acts articulated by scientists in the debate, and by argumentation scholars in their theories, align.

\section{Aligning conceptions of speech acts in theory and practice}

Many issues turned up in scientists' debate over appropriate means of public participation: the nature of scientific practice (e.g., objective v. subjective), the cognitive functions relevant to public policy (e.g., analyzing, integrating), and possible institutional arrangements (e.g., scientist/manager collaborations, advisory committees). Nevertheless, it should be seen as remarkable that a major focus throughout the debate has been a speech activity, advocating. In close alignment with the argumentation theory reviewed in the first section of the paper, scientists take this speech act as providing an overarching framework for the complex, ongoing interactions they seek to have with members of the public and policy-makers. Furthermore, scientists like theorists recognize that the speech act has an intimate connection with argumentation; one of the key tasks of the scientist-advocate is precisely to make good arguments. Based on the evidence of this case, we can therefore conclude that speech act approaches have a strong "conventional validity" as a theory of argumentation.

Among the three specific approaches discussed in the first section of this paper, it is that of Fred Kauffeld which seems to resonate best with scientists' own way of conceptualizing advocating. In their discussions of the speech act, scientists do not focus on what the advocate is advocatingon the specific propositions that the advocate is committed to defend, as 
would be predicted by both Houtlosser and Jackson. Instead, scientists are attending closely to the extent of the advocate's commitment, and in particular whether as scientists they have enhanced commitments, over and above those of ordinary advocates. As we saw, in the debate scientists are concerned with questions like: Ought the scientist-advocate report uncertainties, caveats, limitations? Ought she reveal strong arguments against her view? Ought she select arguments on the basis of their scientific strength, or on the basis of their persuasiveness with the given audience? And ought she give up her position when the science tends against her? In debating these points, scientists, like Kauffeld, take the speech activity of advocating to be a particular package of commitments, and in particular commitments to make arguments of a certain quality.

Scientists' understanding of the specific obligations undertaken by the advocate also aligns well with recent work that follows Kauffeld. In a paper reviewing the codes of conduct developed by professional advocates in law and public relations (Goodwin, 2013), I have advanced a preliminary account of the obligations that constitute advocating. In agreement with scientists' basic definitions of the speech activity, I argued that an advocate's primary commitment is to the zealous support of a particular proposition, person, or cause. At the same time, advocates also undertake an obligation to maintain the integrity of the communication system within which they communicate. For example, advocates must avoid known falsehoods and be able to defend what they do put forward with at least minimally plausible arguments; otherwise their statements would be completely untrustworthy. Although scientists do not discuss the obligations of advocating in this level of detail, their understanding of the conflicts between advocating and the practice of science reveal just these areas of concern. Whereas the practice of science requires telling "the whole truth" about uncertainties and counterconsiderations, scientists rightly recognize that advocates do not have this obligation, and indeed will work hard to suppress such information if it hurts their overall cases.

The account of advocating that I have proposed also tends to reinforce the legitimacy of scientists' concerns about the impact of advocacy on scientific credibility. On the one hand, an advocate is obligated to show zeal for his cause, investing much more effort and passion than speakers are ordinarily obliged to use in defending their statements. From this perspective, advocacy for wilderness preservation or biodiversity can be seen as noble and inspiring. But it is also the case that an advocate owes a much weaker obligation to his audience than is ordinarily the case. So from the perspective of the audience, advocates are viewed with legitimate suspicion, and 


\section{Jean Goodwin}

their statements subjected to careful scrutiny - if they are listened to at all. Scientists are thus rightly cautious about joining the ranks of lawyers, publicity agents, lobbyists and other advocacy professionals.

Is it possible to integrate the advocate's zealous defense of a cause with the scientist's heightened commitments to truth? Can there be an advocacyplus - a responsible advocacy, as some scientists argued? Within a Gricean approach to speech acts, there is in principle no problem with combining various commitments. A speech act is in part a bundle of commitments; there are many more ways of going about acting with language than are picked out and given names, and language users are constantly creating new options. So there is no reason that (for example) one could not undertake both to advocate and to do so using only sentences found in the first edition of The Sorrows of Young Werther. The question is not whether such a novel bundling of commitments is possible, but rather whether it is pragmatically plausible: whether this bundle would give the addressee of the act a reason to respond as expected. Unfortunately, scientists proposing to undertake the extra obligations of a responsible advocate will likely encounter a routine pragmatic difficulty. As above, addressees rightfully are suspicious of what an advocate says, since the advocate owes them little more than the avoidance of outright lying. This attitude of distrust will extend to any metadiscursive comments that the advocate tries to provide. This means that although a scientist-advocate may be sincerely committed to telling the "whole truth," he will likely find it hard to persuade his addressees that this is the case. Absent special reasons for trust, they will dismiss his statements about his extra commitments as just more advocacy — rather like they would dismiss a used car salesman's promise of a special deal, just for them.

From the point of view of speech act theory, a more pragmatically plausible way out of the science/advocacy normative dilemma can be found by taking the other route suggested in the scientists' debate: by looking for other ways for scientists to participate in policy controversies. There are many speech acts and activities through which scientific knowledge might be communicated, and many of them involve commitments that are more compatible with the norms of science. Scientists in the debate occasionally mention educating, for example; a cluster of speech acts pragmatically designed to convey knowledge. Reporting is another commonly used option; in Kauffeld's recent account, reports are "designed to facilitate their critical appropriation by self-reliant lay [i.e., non-expert] addressees" (2012, p. 238). Perhaps most promising of the alternatives is the speech act advising. In fact, the term is often used in the debate interchangeably with "advocacy" (e.g., Meyer et al., 2010). Advice is generally given where there is 
an asymmetry of knowledge - where one person is trying to make a decision, while another knows more about case. The expert would like to help, but is correctly afraid that her intervention might appear to be presumptuous meddling with her addressee's concerns. The commitments undertaken in the act of advising are expressly intended to manage this pragmatic difficulty. Turning to Kauffeld again: "where a speaker gives advice, (i) she tells the advisee something which she at least purports to believe he needs to know, and (ii) she openly takes responsibility for trying assist him in determining what to do about his concerns" (Kauffeld, 1999). In advising, in other words, the speaker openly undertakes to promote her addressee's interests, not her own policy decision. Since both the scientist and her addressee presumably share an interest in the best scientific knowledge available, it should be less normatively stressful to be a scientist-advisor than a scientist-advocate.

Thus far, I have noted convergences between scientists' and argumentation theorists' conceptions of speech acts, and also several ways in which the theorists might contribute to clarifying the debate. Let me close by acknowledging one area in which theorists might learn from practitioners. As the overview of the debate in Section 2 of this paper showed, some proponents of advocacy by scientists argue strongly that such advocacy is in fact normatively required. All citizens have the duty to advocate for what they believe; scientists, being uniquely positioned both with respect to knowledge and reasoning abilities, have a higher responsibility to do so. Although argumentation theorists have devoted significant attention to the obligations that are undertaken in speech acts, they have given less thought to possible obligations to commit a given speech at all. Houtlosser, Jackson and Kauffeld all take the speech acts which initiate argumentative interactions as in some basic way conditional on other interests or activities: if you want to enter into a critical discussion, if you want to keep the conversation going, if you want to address one of a number of recurrent interpersonal difficulties, then you use the appropriate speech act, which obligates you to be ready with arguments. But why should you do so? Fabio Paglieri (Paglieri \& Castelfranchi, 2010) is perhaps the only argumentation theorist who has addressed this problem, but even he examines only the costs and benefits of initiating an argumentative interaction, not the possible obligation to do so. Argumentation theorists interested in developing any of the speech act approaches further may want to add to their research agendas the question of why the initiating speech acts ought to get made.

This essay has attempted to advance our understanding of the speech activity of advocating and its usefulness in communicating science in controversial policy contexts. Independent of this particular aim, however, I hope 


\section{Jean Goodwin}

it has also served as a demonstration of the usefulness of working along a theory-practice continuum. Theorists can help practitioners better articulate, organize, ground and critique the conceptions of speech acts that are already partially articulate in their practice. Practitioners, in turn, can offer theorists a chance to see how (or whether) their abstract conceptions of speech acts play out when confronted with the pragmatic challenges of maintaining good argumentative interactions among people who disagree. Since there are many speech acts of interest to argumentation theorists, and many communities of arguers facing pragmatic challenges, we can look forward to many future conversations between theorists and practitioners of argumentation.

Acknowledgements: This paper benefited from the very useful comments of two reviewers, to whom the author extends her thanks. The research reported here was supported by a grant from the Center for Excellence in the Arts \& Humanities at Iowa State University.

\section{R E F E R E N C E S}

Aron, William, Burke, William, \& Freeman, Milton. (2002). Scientists versus whaling: Science, advocacy, and errors of judgment. BioScience, 52(12), 1137.

Austin, J.L. (1962). How to do things with words. Oxford: Clarendon Press.

Barry, Dwight, \& Oelschlaeger, Max. (1996). A science for survival: Values and conservation biology. Conservation Biology, 10(3), 905-911.

Blockstein, David E. (2002). How to lose your political virginity while keeping your scientific credibility. BioScience, 52(1), 91-96.

Brussard, Peter F. \& Tull, John C. (2007). Conservation biology and four types of advocacy. Conservation Biology, 21(1), 21-24.

Craig, Robert T. (1996). Practical-theoretical argumentation. Argumentation, 10, 461-474.

Craig, Robert T. (1999). Metadiscourse, theory, and practice. Research on Language and Social Interaction, 32, 21-29.

Craig, Robert T. (2011). The uses of "argument" in practical metadiscourse. In Robert C. Rowland (Ed.), Reasoned argument and social change (pp. 7686). Washington, DC: National Communication Association.

Craig, Robert T. \& Tracy, Karen. (1995). Grounded practical theory: The case of intellectual discussion. Communication Theory, 5(3), 248-272.

Craig, Robert T. \& Tracy, Karen. (2010). Framing discourse as argument in appellate courtrooms: Three cases on same-sex marriage. In Dennis S. Gouran (Ed.), The functions of argument and social change (pp. 46-53). Washington, DC: National Communication Association. 
Conceptions of Speech Acts in the Theory and Practice of Argumentation...

Doury, Marianne. (2008). "Ce n'est pas un argument!" Sur quelques aspects de théorisations spontanées de l'argumentation. Pratiques, 139/140, 111-128.

Eemeren, Frans H. van \& Grootendorst, Rob. (1984). Speech acts in argumentative discussions. Dordrecht: Foris.

Eemeren, Frans H. van, Grootendorst, Rob, Jackson, Sally, \& Jacobs, Scott. (1993). Reconstructing argumentative discourse. Tuscaloosa and London: University of Alabama Press.

Ehninger, Douglas \& Brockriede, Wayne. (1963). Decision by debate. New York: Dodd, Mead \& Co.

Foote, Lee, Krogman, Naomi \& Spence, John. (2009). Should academics advocate on environmental issues? Society and Natural Resources, 22(6), 579-589.

Gill, Bruce R. (2001). Professionalism, advocacy, and credibility: A futile cycle? Human Dimensions of Wildlife, 6(1), 21-32.

Goodwin, Jean. (2007a). Argument has no function. Informal Logic, 27, 69-90.

Goodwin, Jean. (2007b). What, in practice, is an argument? In Hans V. Hansen, Christopher W. Tindale, J. Anthony Blair \& Ralph H. Johnson (Eds.), Dissensus and the search for common ground (pp. 1-44). Windsor, ON: OSSA.

Goodwin, Jean. (2013). Norms of advocacy. In Dima Mohammed \& Marcin Lewiński (Eds.), Virtues of Argumentation (pp. 1-18). Windsor, Ontario: OSSA.

Grice, H.P. (1957). Meaning. Philosophical Review, 62, 397-388.

Houtlosser, Peter. (1994). The speech act "advancing a standpoint". In Frans H van Eeemeren \& Rob Grotendorst (Eds.), Studies in pragma-dialectics (pp. 165171): SicSat.

Houtlosser, Peter. (1998). Points of view. Argumentation, 12(3), 387-405.

Houtlosser, Peter. (2002). Indicators of a point of view. In Frans H. Van Eemeren (Ed.), Advances in pragma-dialectics (pp. 169-184). Amsterdam: SicSat.

Jackson, Sally. (1985). What can speech acts do for argumentation theory? In J. Robert Cox, Malcolm O. Sillars \& Gregg B. Walker (Eds.), Argument and social practice (pp. 127-138). Annandale, VA: National Communication Association.

Jackson, Sally. (1992). Virtual standpoints and the pragmatics of conversational argument. In Frans H. van Eemeren, Rob Grootendorst, J. Anthony Blair \& Charles A. Willard (Eds.), Argumentation illuminated (pp. 260-269). Amsterdam: SicSat.

Johnson, Ralph H. (2000). Manifest rationality: A pragmatic theory of argument. Mahwah, NJ: Lawrence Erlbaum Associates.

Karr, James R. (2006). When government ignores science, scientists should speak up. BioScience, 56(4), 287-288.

Kauffeld, Fred J. (1995). The persuasive force of arguments on behalf of proposals. In Frans H. van Eemeren, Rob Grootendorst, J. Anthony Blair \& Charles 


\section{Jean Goodwin}

A. Willard (Eds.), Analysis and evaluation: Proceedings of the third ISSA conference on argumentation (Vol. II, pp. 79-90). Amsterdam: International Centre for the Study of Argumentation.

Kauffeld, Fred J. (1998). Presumptions and the distribution of argumentative burdens in acts of proposing and accusing. Argumentation, 12(2), 245-266.

Kauffeld, Fred J. (1999). Arguments on the dialectical tier as structured by proposing and advising. In Christopher W. Tindale, Hans V. Hansen \& Elmar Sveda (Eds.), Argumentation at the century's turn: Proceedings of the third OSSA Conference. St. Catharines, ON: OSSA.

Kauffeld, Fred J. (2001). Argumentation, discourse, and the rationality underlying Grice's analysis of utterance-meaning. In Eniko T. Nemeth (Ed.), Cognition in language use: Selected papers from the 7th International Pragmatics Conference (pp. 149-163). Antwerp: International Pragmatics Association.

Kauffeld, Fred J. (2002). Pivotal issues and norms in rhetorical theories of argumentation. In Frans H. van Eemeren \& Peter Houtlosser (Eds.), Dialectic and rhetoric: The warp and woof of argumentation analysis (pp. 97-118). Dordrecht: Kluwer.

Kauffeld, Fred J. (2009). What are we learning about the arguers' probative obligations. In Scott Jacobs (Ed.), Concerning argument (pp. 1-31). Washington, DC: National Communication Association.

Kauffeld, Fred J. (2012). A pragmatic paradox inherent in expert reports addressed to lay citizens. In Jean Goodwin (Ed.), Between scientists 83 citizens: Proceedings of a conference at Iowa State University, June 1-2, 2012 (pp. 229240). Ames, IA: Great Plains Society for the Study of Argumentation.

Kauffeld, Fred J. \& Fields, John. (2003). The presumption of veracity in testimony and gossip. In J. Anthony Blair, Daniel Farr, Hans V. Hansen, Ralph H. Johnson \& Christopher W. Tindale (Eds.), Informal Logic @ 25. Windsor, ONT: Ontario Society for the Study of Argumentation.

Lach, Denise, List, Peter, Steel, Brent \& Shindler, Bruce. (2003). Advocacy and credibility of ecological scientists in resource decisionmaking: A regional study. BioScience, 53(2), 170-178.

Lackey, Robert T. (2007). Science, scientists, and policy advocacy. Conservation Biology, 21(1), 12-17.

Lovejoy, Thomas. (1989). The obligations of a biologist. Conservation Biology, 3(4), 329-330.

Meine, Curt \& Meffe, Gary K. (1996). Conservation values, conservation science: A healthy tension. Conservation Biology, 10(3), 916-917.

Meyer, Judy L., Frumhoff, Peter C., Hamburg, Steven P. \& de la Rosa, Carlos. (2010). Above the din but in the fray: Environmental scientists as effective advocates. Frontiers in Ecology and the Environment, 8(6), 299-305.

Mills, Thomas \& Clark, Roger. (2001). Roles of research scientists in natural resource decision-making. Forest Ecology and Management, 153, 189-198. 
Conceptions of Speech Acts in the Theory and Practice of Argumentation...

Minnis, Donna \& Stout McPeake, Rebecca. (2001). An analysis of advocacy within the wildlife profession. Human Dimensions of Wildlife, 6(1), 1-10.

Moran, Richard. (2006). Getting told and being believed. In Jennifer Lackey \& Ernest Sosa (Eds.), The epistemology of testimony (pp. 272-306). Oxford: Clarendon Press.

Morrison, Thomas A. \& Ayres, Matthew P. (2010). Speaking out: Weighing advocacy and objectivity as a junior scientist. Frontiers in Ecology and the Environment, 8(1), 50-55.

Myers, N. (1999). Environmental scientists: Advocates as well? Environmental Conservation, 26(3), 163-165.

Nelkin, Dorothy. (1977). Scientists and professional responsibility: The experience of American ecologists. Social Studies of Science, 7(1), 75-95.

Nelson, Michael \& Vucetich, John. (2009). On advocacy by environmental scientists: What, whether, why, and how. Conservation Biology, 23(5), 1090-1101.

Nielsen, Larry. (2001). Science and advocacy are different-and we need to keep them that way. Human Dimensions of Wildlife, 6(1), 39-47.

Noss, R. (2007). Values are a good thing in conservation biology. Conservation Biology, 21(1), 18-20.

O'Keefe, Daniel J. (1982). The concepts of argument and arguing. In J. Robert Cox \& Charles Arthur Willard (Eds.), Advances in argumentation theory and research (pp. 3-23). Carbondale: Southern Illinois University Press.

Paglieri, Fabio \& Castelfranchi, Cristiano. (2010). Why argue? Towards a costbenefit analysis of argumentation. Argument \& Computation, 1(1), 71-91.

Philipsen, Gerry. (1992). Speaking culturally: Explorations in social communication. Albany, NY: SUNY Press.

Pielke, Roger A. (2007). The honest broker: Making sense of science in policy and politics. Cambridge: Cambridge University Press.

Plantin, Christian. (1996). L'argumentation. Paris: Le Seuil.

Plantin, Christian. (2002). Argumentation studies and discourse analysis: The French situation and global perspectives. Discourse Studies, 4(3), 343-368.

Schneider, Stephen H. (1988). The greenhouse effect and the US summer of 1988: Cause and effect or a media event? Climatic Change, 13(2), 113-115.

Scott, J. Michael \& Rachlow, Janet L. (2011). Refocusing the debate about advocacy. Conservation Biology, 25(1), 1-3.

Scott, J. Michael, Rachlow, Janet L. \& Lackey, Robert T. (2008). The science-policy interface: What is an appropriate role for professional societies? BioScience, $58(9), 865-869$.

Searle, John R. (1969). Speech acts: An essay in the philosophy of language. Cambridge: Cambridge University Press.

Stampe, Dennis. (1967). On the Acoustic Behavior of Rational Animals. Photocopy. University of Wisconsin-Madison. Madison, WI. 


\section{Jean Goodwin}

Steel, Brent, List, Peter, Lach, Denise \& Shindler, Bruce. (2004). The role of scientists in the environmental policy process: A case study from the American west. Environmental Science and Policy, 7(1), 1-13.

Tracy, C. Richard \& Brussard, Peter F. (1996). The importance of science in conservation biology. Conservation Biology, 10(3), 918-919.

Walton, Douglas. (1998). The new dialectic: Conversational contexts of argument. Mahwah, NJ: Lawrence Erlbaum Associates.

Wiens, John A. (1997). Scientific responsibility and responsible ecology. Conservation Ecology, 1(1), 16. 